УДК 371.334(076) (100)

https://doi.org/10.31548/philolog2020.02.026

\title{
CONVENTIONAL IMPLICATURES IN ENGLISH-BASED LITERARY DISCOURSE: TRIGGERS AND INFERENCE PROCESS
}

\author{
A. B. POZHAR, senior lecture, \\ Kiev National Linguistic University \\ E-mail: anastasiya.pozhar@gmail.com \\ http://orcid.org/ 0000-0001-9821-0740
}

\begin{abstract}
The paper focuses on the triggers of conventional implicatures referring to the human age description in English-based literary discourse. The study aims at identifying the conventional implicatures triggered by temporal adverbs in their age modifying functions. To achieve the purpose, the paper has applied the set of methods: the Grice's and neo-Gricean inferential pragmatics to inference conversational implicatures triggered by temporal adverbs; form / function pragmatics in elucidating conventionally embedded pragmatic meanings as well as some elements of stylistic and contextual interpretation analyses of a literary text.

The major findings refer to the identification of the most frequent adverbial modifiers triggering the conventional implicatures in the age-related narrations in English-based literary discourse. The identified triggers encompass the temporal adverbs still, just, suddenly and recently, which actualize the conventional implicatures due to their presuppositional component of "time continuance" correlating with age semes. The most frequent marker of embedded conventional meanings is the adverb still in its semantic components "so far" and "even if".

Age-related conventional implicatures usually modify the age descriptors of appearance (with the implicature: "at that age, people usually don't look so good") and behavior (with the implicature: at this age, people usually do not behave this way"). Much less frequent are conventional implicatures, associated with age-bound feelings or physical well-being.

The perspective of the undertaken research is the study of the conventional implicatures in the characters' conversational speech of English-based literary discourse.
\end{abstract}

Keywords: conventional implicature, age-related meanings, temporal adverbs, pragmatic, literary discourse.

Introduction. Conversational and conventional implicatures have been traditionally studied on the basis of conversational speech - in view of their specifics as the intentional meanings (either unconventional, triggered by cooperative maxims' flouting or conventional based on the semantical or grammatical items' agreed meanings). However, given the fact that the literary text also represents a kind of communication between the author and the reader, who presumably possess some "shared" knowledge about the usual rules of communication, interaction and cooperation, it seems possible to assume that the author uses specific mechanisms for implicating meanings intended to be inferred by the reader.

The purpose of the article is to identify the conventional implicatures triggered by temporal adverbs in their age modifying functions.

Recent researches and publications. Implicatures have been the focus of numerous linguistic studies. The term "conventional implicature" denoting the implicated while structurally triggered pragmatic phenomenon was first coined and introduced into linguistics by G.P. Grice [9]. Implicature is stated by Grice as a term "to account for what a speaker can imply, suggest, or mean as distinct from what 
speaker literally says" [4, p. 31]. It can occur in any kinds of communication either written or spoken.

As distinct from conversational or discursive implicatures, conventional implicatures are "predictable" since they base on lexical items or other conventional triggers of additional meanings, which are conveyed regardless of the context. The words such as only, too, even, yet, in spite of, already, still as well as implicative verbs like to manage to, to forget to, to force to, etc. may result in the additional conveyed meaning due to some aspects of their semantic structure. A particular facet of recent studies focuses on the problem of conventional implicatures interplay with other pragmatic phenomena, i.e. semantic presuppositions and direct speech acts illocutions [11].

Together with the phenomenon of speech acts, the Gricean notion of implicature has been applied to a literary discourse analysis by J.R. Searle [16], G. Currie [6], M.L. Pratt [13] and other scientists. In the semiotic framework specifics of interplay of pragmatic phenomena in literary text have been studied by [10]. In particular, the scientists have made an attempt to identify some correlations between the author's adherence to Cooperative Principle and the maxims of cooperation and the level of his / her responsivity to the reader's face wishes [op. cit., p. 26].

Data and methods. The research data have been collected from the literary discourse based on the novels by $M$. Cunningham [5], J.D. Salinger [15] and D. Steel [18].

In data processing we have applied descriptive qualitative approach within the framework of conventional implicatures analysis with regard to their indexing triggers $[9 ; 12 ; 14 ; 17]$. The paper mostly relies on adverbial modifiers as the markers of conventional implicature, associated with the age meanings. The research methodology involves the following research methods: the Grice's and neoGricean inferential pragmatics to inference conversational implicatures triggered by temporal adverbs; form / function pragmatics in elucidating conventionally embedded pragmatic meanings [1, p. 30] as well as some elements of stylistic and contextual interpretation analyses of a literary text.

Results. The research focus of this article has been the triggers of conventional implications, related to the actualization of "age" meanings. It is identified that the most frequent triggers of such implications include the adverbs still, just, suddenly, recently, which in their presuppositional meanings contain temporal semes. The most common marker is the adverb still, which usually triggers the conventional implicature due to its presuppositional meaning "so far", associated with the age, as well as the semantic component of "whatever" as in (1).

(1)You're still very young [18, p. 166] (implicature: She is not young by her biological age or by her feeling of one's biological age) A model with conventional implicatures can be schematically represented as follows:

Convlmpl (VN1) \# VN2 (impl),

where ConvImpl means Conventional Implicature, VN1 denotes the first (explicated) verbal nominative of age), VN2 refers to the second (implicit) age meaning contradicting to VN1, which is indicated by \#.

Usually, the temporal adverb still modifies either the age descriptor of appearance (with the implicature: "at that age, people usually don't look so good" as in (2), (3) and (5), or the behavioral descriptor (with the implicature: at this age, people usually do not behave this way" as in (4).

(2) her mother was sixty-one, and still a good-looking woman [18, p. 257] (implicature: at sixty-one people usually don't look that good); Model: VN \# Convimpl (VD-appearance), where VN refers to verbal nominative of age and VDappearance denotes the verbal descriptive of appearance, modified by Conventional Implicature so as to contradict to VN. 
(3) She hardly had any wrinkles, and still had a trim figure [18, p. 361] (implicature: at her age, people usually don't look so good); Model: VD 1appearance $<>$ VD 2-appearance \# Convlmpl (VN (impl)), displaying that two mutually supportive verbal descriptors of appearance mismatch the verbal nominative, triggered by Conventional Implicature.

(4) At sixty-one, she was still working [18, p. 26] (implicature: at sixty-one a person may no longer work); Model: VN \# ConvImpl (VD-behavior) displaying that that the verbal descriptor of behavior supported by Conventional Implicature, mismatches the verbal nominative.

Fragment (5) involves two triggers of conventional implicature: the adverb "still", which actualizes an additional meaning "at forty-two, women usually do not look thirty", and the presuppositional verb "looked", triggering the local conventional implicature "he just makes that impression, he's not really that young anymore".

(5) At forty-two, he still looked thirty, and was in fantastic shape [18, p. 31] (Model: VN1 \# Convlmpl (VN2) < VD(appearance), showing that the second verbal nominative of age (VN2) supported both by Conventional Implicature and the verbal descriptor of appearance mismatches the first verbal nominative (VN1).

Less frequent is the implicature, related to the characteristic of physical well-being as in (6) or feelings stereotypically associated with a certain age, such as in (7) and (8).

(6) Her memory is still excellent [18, $p$. 282] (implicature: at her age, people usually have some memory problems, that is, she is an elderly person); Model: Convlmpl (VNimpl) \# VD (physical well-being).

(7) He said he was still a child himself [18, p. 293] (implicature: he feels like a child despite his age); Model: Convimpl (VD (feeling)) < (VN1) \# VN2 (impl).

(8) They were both around seventy years old, or even more than that $(\ldots)$ you wondered what the heck he was still living for. I mean he was all stooped over, and he had very terrible posture [15, p. 4] (implicature indicated by still: usually at his age and in his physical form others do not feel the meaning of life); Model: VN <> Convimpl (VD (feeling)) \# VD (appearance).

Therefore, the adverb still is one of the most frequent triggers of conventional implicature in the analyzed literary discourse, which is understandable given the correlation of the meanings "age" and "continuance" (constituting the adverb's semantics), with the same category of time.

The analysis the actualization process and the meaningful functions of the conventional implicature indexed by the adverb still in conjunction with other triggers of conventional meanings as in (9) allowed us to make a number of interesting observations.

(9) She is still regal, still exquisitely formed, still possessed of her formidable lunar radiance, but she is suddenly no longer beautiful [5, p. 33].

In particular, in the above text snippet, the adverb still triggers the conventional implicature, based on two components of the adverb's meaning: "so far" and "regardless of the fact that / even if". Therefore, the adverb is a modifier of the age descriptor "she looks good", adding the interrelated additional meanings "so far" and "despite what was / will be said about her appearance".

In the analyzed snippet, we identiied another trigger of conventional implicature - the advervial modifier "suddenly", which modifies the age descriptor "no longer beautiful" by the conventional (i.e, associated with the semantics of modifier) meaning "the unexpected and therefore the dramatic age changes".

The set of conventional implicatures, triggered by age-modifying adverbs, forms a kind of semantic coherence of the text, based on the relations of the antithesis: she looks good despite the age-related changes (triple repetition of still - however, unexpected and dramatic age-related changes are obvious to her. Consequently, the conventional 
implicature of the whole utterance that integrates several "local" implicit meanings can be inferred as follows: it is hard for her to put up with the fact that she is getting older.

A model with conventional implicatures can be schematically represented as follows:

3 Conlmpl (VD-appearance) \# Conlmpl (VD-appearance).

In the stylistic framework the semantic and syntactic distribution of the conventional implicatures' triggers provide here the stylistic device of gradation - the change of climax by retardation (anticlimax), which conveys the narrator's feeling: the discouraging fact of an unexpected aging of the wife is replaced by the temporary emotional uplift (three time repetition of the "optimistic" still) which, in turn, is followed by the emotional stress release and reconciliation with the obvious.

Applying to the semantic analysis of this fragment the terminology of syntactic stylistics, it is possible, in our opinion, to equate the location of meanings, marked by conventional implicatures and their actualizing devices, with framing or ring repetition - with a repetition of the same implicit meaning at the beginning and at the end of the fragment.

\section{References}

1.Ariel, M. (2012). Research paradigms in pragmatics. The Cambridge handbook of pragmatics In Allan, K. \& Jaszczolt, K.M. (Eds.). New York: Cambridge University Press, 23-45.

2. Beaver, D. (1997). Presupposition. The handbook of logic and language. Van Benthem, J. \& A. ter Meulen, A. (eds.). Amsterdam: Elsevier, 939-1008.

3. Beaver, D. (2001). Presupposition and assertion in dynamic semantics. Stanford: CA: CSLI Publications.

4. Brown, G. \& Yule, G. (1983). Discourse Analysis. New York: Cambridge University Press.

5. Cunningham, M. (2000). The Hours. Picador Modern Classics.

6. Currie, G. (2006). "Why Irony is Pretence". The Architecture of the Imagination: New Essays on Pretence,
Conclusions. The paper has identified the most frequent triggers of conventional implicatures associated with "age meanings", in a literary discourse. These markers include the temporal adverbs still, just, suddenly and recently, capable to trigger the implicated "age-bound" conventional meanings due to these words presuppositional component "time continuance" correlating with the age's semes. The most frequent among them is the adverb still indicating conventional implicatures, based on two constituents of its meaning: "so far" and "regardless of the fact that / even if".

Inferred conventional implicatures usually modify the age descriptors of appearance (with the implicature: "at that age, people usually don't look so good") and behavior (with the implicature: at this age, people usually do not behave this way"). Much less frequent are conventional implicatures, related to the physical well-being or feelings typical for a particular age.

The perspective of the undertaken research is the study of the conventional implicatures in the characters' conversational speech of English-based literary discourse.

Possibility, and Fiction. Shaun Nichols (ed.). Oxford: Clarendon Press, 111-136.

7. Frapolli, M.J. \& Fernandez, N. V. (2007). Inference markers and conventional implicatures. Teorema: International Journal of Philosophy, 26 (2), 124-140.

8. Grice, H. P. (1975). Logic and Conversation. Syntax and Semantics: Speech Acts, 3, 41-58.

9. Grice, H. P. (1991). Studies in the Way of Words. Cambridge: Harvard University Press, 78-79.

10. Kravchenko, N. \& Yudenko, A. (2019). Communicative conventions and literary text: specifics of interplay. Science and Education: A New Dimension. Philology, VII (62), 211, 26-29.

11. Kravchenko, N. (2017). Illocution of direct speech acts via conventional implicature and semantic presupposition. Lege artis. Language yesterday, today, 
tomorrow. The Journal of University of SS Cyril and Methodius in Trnava. Warsaw: De Gruyter Open, II(1), 128-168.

12. Potts, C. (2007). Into the Conventional-Implicature Dimension. Philosophy Compass, 2(4), 665-679.

13. Pratt, M. L. (1977). Toward a Speech Act Theory of Literary Discourse. Bloomington: Indiana University Press.

14. Recanati, F. (2003). Embedded Implicatures. Philosophical Perspectives, 17 (1), 299-332.

15. Salinger, J.D. (2018). The Catcher in the Rye. Penguin Books Ltd.

16. Searle, John R. (1985). Expression and Meaning. Cambridge: Cambridge University Press.

17. Simons, M. (2001). On the conversational basis of some presuppositions. In Proceedings of semantics and linguistics theory. Hastings, R., Jackson, B. \& Zvolensky Z. (eds.). Ithaca, NY: CLC Publications, 431-448.

18. Steel, D. (2007). The House. A Del Book.

19. Sharvit, Y \& Gajewski J. (2012). In Defense of the Grammatical Approach to Local Implicatures. Natural Language Semantics, 20 (1), 31-57.

\section{КОНВЕНЦІЙНІ ІМПЛІКАТУРИ В АНГЛОМОВНОМУ ХУДОЖНЬОМУ ДИСКУРСІ: ТРИГЕРИ І ПРОЦЕС ІНФЕРЕНЦІЇ}

\section{А. Б. Пожар}

Анотація. У статті висвітлюється тригери конвенційної імплікатури, що співвідносні з описом вікових значень в англомовному художньому дискурсі. Мета статmі - виявлення конвенційних імплікатур, маркованих прислівниками часу, здатними модифрікувати описані текстом вікові значення. Для досягнення поставленої мети використовувалася низка методів: Грайсіанська і нео-грайсіанська інфреренційна прагматика для вилучення конвнційних імплікатур, маркованих прислівниками часу; формально-функційна прагматика для ідентифрікації конвенційно вбудованих прагматичних значень, а також елементи стилістичного $i$ контекстуально-інтерпретаційного аналізу художнього тексту.

Основні результати дослідження стосуються ідентифрікації найбільш частотних адвербіальних модифрікаторів, що є тригерами конвенційних імплікатур у нараціях, дотичних до позначення віку у англомовному художньому дискурсі. Ідентифріковані тригери включають прислівники часу still, just, suddenly i recently, які актуалізують конвенційні імплікатури завдяки наявності в їхній семантиці пресупозиційного компоненту «протяжність у часі», що корелює з віковими семами. Найчастотнішим маркером «вбудованого» конвенційного значення є прислівник still через наявність в його семантичній структурі семантичних компонентів "so far" $i$ "even if".

Конвенційні імплікатури, пов'язані із значеннями віку, зазвичай модифрікують вікові дескриптори зовнішності (імплікатурою «в такому віці люди зазвичай так добре не виглядають») $і$ поведінки (імплікатурою «в такому віці люди зазвичай так не поводяться»). Набагато менш частотними є конвенційні імплікатури, асоційовані $з$ фрізичним самопочуттям і відчуттями, характерними для певного віку.

Перспективою подальших досліджень $є$ вивчення тригерів конвенційних імплікатур у діалогічному мовленні персонажів англомовного художнього дискурсу.

Ключові слова: конвенційна імплікатура, вікові значення, прислівники часу, прагматичний, художній дискурс. 